\title{
DNA Interaction Studies of a New Platinum(II) Complex Containing Different Aromatic Dinitrogen Ligands
}

\author{
Nahid Shahabadi, ${ }^{1}$ Somaye Mohammadi, ${ }^{1}$ and Robabeh Alizadeh ${ }^{2}$ \\ ${ }^{1}$ Department of Inorganic Chemistry, Faculty of Chemistry, Razi University, Kermanshah 74155, Iran \\ ${ }^{2}$ School of Chemistry, Damghan University, Damghan, Iran
}

Correspondence should be addressed to Nahid Shahabadi, nahidshahabadi@yahoo.com

Received 20 July 2011; Revised 12 September 2011; Accepted 13 September 2011

Academic Editor: Zhe-Sheng Chen

Copyright ( 2011 Nahid Shahabadi et al. This is an open access article distributed under the Creative Commons Attribution License, which permits unrestricted use, distribution, and reproduction in any medium, provided the original work is properly cited.

\begin{abstract}
A new mononuclear $\mathrm{Pt}(\mathrm{II})$ complex, $[\mathrm{Pt}(\mathrm{DMP})(\mathrm{DIP})] \mathrm{Cl}_{2} \cdot \mathrm{H}_{2} \mathrm{O}$, in which DMP is 4,4-dimethyl-2,2-bipyridine and DIP is 4,7-diphenyl-1,10-phenantroline, has been synthesized and characterized by physicochemical and spectroscopic methods. The binding interaction of this complex with calf thymus DNA (CT-DNA) was investigated using fluorimetry, spectrophotometry, circular dichroism, viscosimetry and cyclic voltametry (CV). UV-VIS spectrum showed $4 \mathrm{~nm}$ bathochromic shift of the absorption band at $280 \mathrm{~nm}$ along with significant hypochromicity for the absorption band of the complex. The intrnisic binding constant $\left(K_{b}=2 \times\right.$ $\left.10^{4} \mathrm{M}^{-1}\right)$ is more in keeping with intercalators and suggests this binding mode. The viscosity measurements showed that the complex-DNA interaction can be hydrophobic and confirm intercalation. Moreover, the complex induced detectable changes in the CD spectrum of CT-DNA. The fluorescence studies revealed that the probable quenching mechanism of fluorescence of the complex by CT-DNA is static quenching. The thermodynamic parameters $(\Delta H>0$ and $\Delta S>0)$ showed that main interaction with hydrogenic forces occurred that is intercalation mode. Also, CV results confirm this mode because, with increasing the CT-DNA concentration, shift to higher potential was observed.
\end{abstract}

\section{Introduction}

During the recent years, only some platinum compounds such as cisplatin, carboplatin, and more recently nedaplatin and oxaliplatin have been known as antitumor compounds in clinical treatments; the research in this field is still increasing [1-5]. The original studies of metallointercalators centered on square planar platinum(II) complexes containing phenanthroline ligand $[6,7]$. Octahedral transition metal complexes containing three bipyridine or phenanthroline ligands have been shown to be groove binders or possible partial intercalators $[8,9]$. Concerning the noncovalent interactions between transition metal complexes and DNA, they can occur by intercalation, groove binding, or external electrostatic binding [10]. In general, metal complexes upon binding to DNA are stabilized through a series of weak interactions such as the $\pi$-stacking interactions of aromatic heterocyclic groups between the base pairs (intercalation), hydrogen bonding, and van der Waals interactions of functional groups bound along the groove of the DNA helix [11]. Platinum compounds are an important part of the first line of treatment for many types of cancers such as testicular and ovarian cancer. Cisplatin, cis- $\left[\mathrm{PtCl}_{2}\left(\mathrm{NH}_{3}\right)_{2}\right]$, and carboplatin, $\mathrm{Pt}(\mathrm{cbca})\left(\mathrm{NH}_{3}\right)_{2}$ with cbca = 1,1-cyclobutanedicarboxylate, has been in use clinically for more than 30 years. Recently, oxaliplatin, $\mathrm{Pt}(\mathrm{dach})(\mathrm{ox})$ where dach $=\mathrm{R}, \mathrm{R}$ 1,2-diaminocycloexane and ox $=$ oxalate, a third generation of Pt complexes have been approved for clinical use [12]. McFadyen et al. [13] synthesized a range of $\mathrm{Pt}(\mathrm{II})$ complexes containing substituted phenanthroline ligands and showed that the complex $\left[\mathrm{Pt}(\mathrm{en})\left(3,4,7,8-\mathrm{Me}_{4}\right.\right.$ phen $\left.)\right] \mathrm{Cl}_{2}$ was two or three times more active than the corresponding phen-based complex $[\mathrm{Pt}(\mathrm{en})(\mathrm{phen})] \mathrm{Cl}_{2}$, against murine leukemia cell lines. In this context, we report the results of an investigation of the interaction with calf thymus DNA of the complex $[\mathrm{Pt}(\mathrm{DMP})(\mathrm{DIP})] \mathrm{Cl}_{2} \cdot \mathrm{H}_{2} \mathrm{O}$. The data were further compared with previous results [14] to determine the effect of metal on the DNA binding mode. Many techniques have 
been applied for investigation of the interaction of metal complexes with DNA. These include (i) molecular spectroscopy methods such as UV spectrophotometry [15], fluorescence [16], circular dichroism spectroscopy [17, 18], dynamic viscosity measurements $[19,20]$, and high-performance liquid chromatography [21]. Between these techniques, UV spectrophotometry, fluorescence method, dynamic viscosity measurements circular dichroism, and cyclic voltametry studies have been preferred because small molecule-DNA interaction may be experimentally monitored by changes in the intensity and position of the spectroscopic peak responses or changes in dynamic viscosity of DNA.

\section{Experimental}

All chemicals such as $\mathrm{K}_{2} \mathrm{PtCl}_{4}, 4,7$-dimethyl-1,10-phenanthroline, and 4,4-dimethyl-2,2-bypyridine, were purchased from Merck, and Tris- $\mathrm{HCl}$ and highly polymerized calf thymus DNA (CT-DNA) were purchased from Sigma Co.. Experiments were carried out in Tris- $\mathrm{HCl}$ buffer at $\mathrm{pH}$ 7.0. A solution of calf thymus DNA gave a ratio of UV absorbance at 260 and $280 \mathrm{~nm}$ more than 1.8, indicating that DNA was sufficiently free from protein [22]. The stock solution of CTDNA was prepared by dissolving DNA in $10 \mathrm{mM}$ of the Tris$\mathrm{HCl}$ buffer at $\mathrm{pH}$ 7.0. The DNA concentration (monomer units) of the stock solution $\left(1 \times 10^{-2} \mathrm{M}\right.$ per nucleotide $)$ was determined by UV spectrophotometer, in properly diluted samples, using the molar absorption coefficient $6600 \mathrm{M}^{-1} \mathrm{~cm}^{-1}$ at $258 \mathrm{~nm}$ [23]. The stock solutions were stored at $4^{\circ} \mathrm{C}$ and used over no more than 4 days.

2.1. Synthesis of the $[\mathrm{Pt}(\mathrm{DMP})(\mathrm{DIP})] \mathrm{Cl}_{2} \cdot \mathrm{H}_{2} \mathrm{O}$ Complex. $[\mathrm{Pt}(\mathrm{DMP})(\mathrm{DIP})] \mathrm{Cl}_{2} \cdot \mathrm{H}_{2} \mathrm{O}$ (Figure 1 ) was synthesized by two steps. In the first step the platinum precursor, $\mathrm{K}_{2} \mathrm{PtCl}_{4}$, the $(0.05 \mathrm{~g}, 0.12 \mathrm{mmol})$ was dissolved in $6 \mathrm{~mL}$ of water and a solution of 4,4-dimethyl-2,2-bipyridine $(0.022,0.12 \mathrm{mmol})$ was added dropwise. The mixture was stirred overnight at $50^{\circ} \mathrm{C}$. A yellow precipitate was formed, which was filtered off and washed with ice-cold water and acetone. Subsequently in second step the prepared precipitate in first step $(0.03 \mathrm{~g}$, $0.1 \mathrm{mmol}$ ) was dissolved in $4 \mathrm{~mL}$ methanol and a solution of 4,7-diphenyl-1,10-phenantroline $(0.027 \mathrm{~g}, 0.1 \mathrm{mmol})$ in $4 \mathrm{~mL}$ methanol was added dropwise. The last solution was refluxed in $180^{\circ} \mathrm{C}$ for $4 \mathrm{~h}$. A green precipitate was formed, which was filtered off and washed with ice-cold water and diethylether. Yield: $36 \%$. Elemental analysis for $\mathrm{PtC}_{36} \mathrm{H}_{28} \mathrm{~N}_{4}$ $\mathrm{Cl}_{2} \mathrm{H}_{2} \mathrm{O}$ : found: $\mathrm{C}, 53.2 ; \mathrm{H}, 4.1 ; \mathrm{N}, 6.9 \%$; calc.: C, $54.1 ; \mathrm{H}$, 3.6; N, 7.0\%; FT-IR $\left(\mathrm{KBr}, \mathrm{cm}^{-1}\right): 3050-3236[v(\mathrm{C}-\mathrm{H})], 1230$ $[v(\mathrm{C}-\mathrm{N})], 1560[v(\mathrm{C}=\mathrm{N})], 532[v(\mathrm{Pt}-\mathrm{N})], 3400-3500[v$ $\left.\left(\mathrm{H}_{2} \mathrm{O}\right)\right]$.

2.2. Instrumentation. ${ }^{1} \mathrm{H}$ NMR spectra were recorded with using a Bruker Avance DPX200 MHz (4.7 T) spectrometer using d6-DMSO as solvent. The elemental analysis was performed using Heraeus CHN elemental analyzer. Absorbance spectra were recorded using a hp spectrophotometer (agilent 8453) equipped with a thermostated bath (Huberpolysat cc1). Absorption titration experiments were carried out by

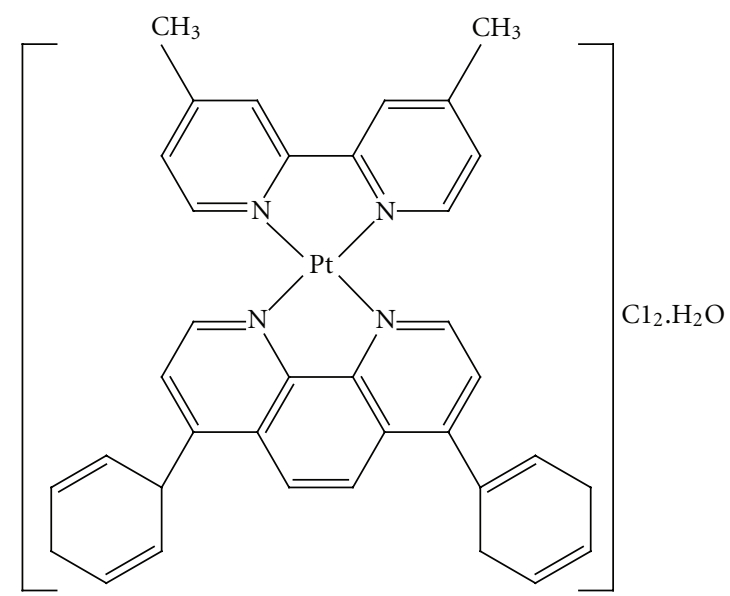

Figure 1: The structure of $[\mathrm{Pt}(\mathrm{DMP})(\mathrm{DIP})] \mathrm{Cl}_{2} \cdot \mathrm{H}_{2} \mathrm{O}$ complex.

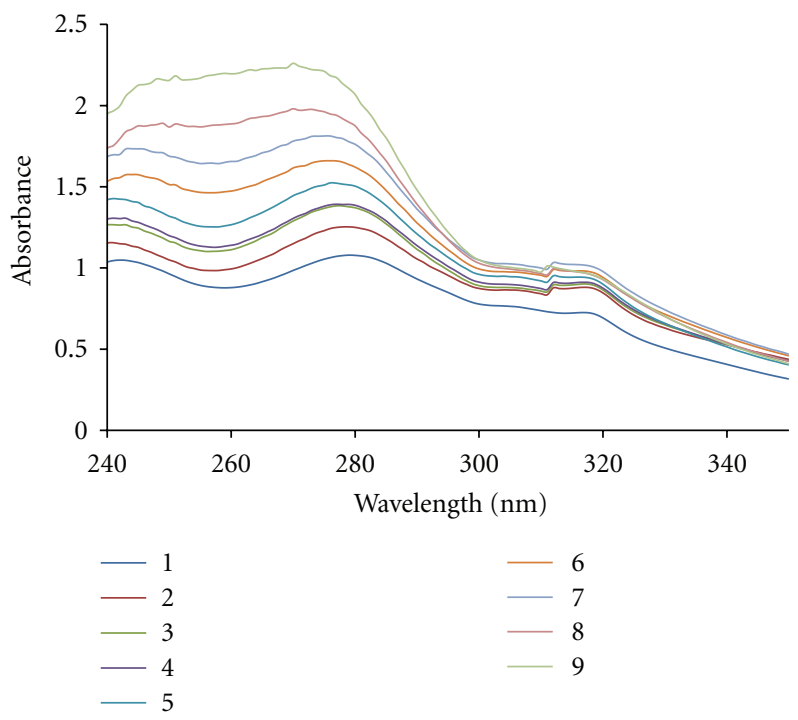

Figure 2: Absorption spectra of DNA $\left(5 \times 10^{-5} \mathrm{M}\right)$ in the absence and in the presence of increasing amounts of platinum complex (ri $=[\mathrm{DNA}] /[$ complex $]$ ).

keeping the concentration of DNA constant $\left(5 \times 10^{-5} \mathrm{M}\right)$ while varying the complex concentration from $5 \times 10^{-5} \mathrm{M}$ to $4 \times 10^{-4} \mathrm{M}(\mathrm{ri}=[\mathrm{DNA}] /[$ complex $]=0-4)$.

Absorbance values were recorded after each successive addition of DNA solution and equilibration (ca. $10 \mathrm{~min}$ ) (Figure 2). The data were then fitted to (1) to obtain intrinsic binding constant, $K_{b}[24]$ :

$$
\frac{[\mathrm{DNA}]}{\left(\varepsilon_{a}-\varepsilon_{f}\right)}=\frac{[\mathrm{DNA}]}{\left(\varepsilon_{b}-\varepsilon_{f}\right)}+\frac{1}{K_{b}\left(\varepsilon_{b}-\varepsilon_{f}\right)}
$$

where $\varepsilon_{a}, \varepsilon_{f}$, and $\varepsilon_{b}$ are the apparent, free and bound complex extinction coefficients, respectively. In particular, $\varepsilon_{f}$ was determined by a calibration curve of the isolated metal complex in aqueous solution; following the Beer's law, $\varepsilon_{a}$ was determined as the ratio between the measured absorbance and the Pt(II) complex concentration, Aobs/[Pt]. A plot of 
[DNA] $/\left(\varepsilon_{a}-\varepsilon_{f}\right)$ versus [DNA] gave a slope of $1 /\left(\varepsilon_{b}-\varepsilon_{f}\right)$ and a $Y$ intercept equal to $1 / K_{b}\left(\varepsilon_{b}-\varepsilon_{f}\right) ; K_{b}$ is the ratio of the slope to the $Y$ intercept. CD measurements were recorded on a JASCO (J-810) spectropolarimeter, keeping the concentration of DNA constant $\left(5 \times 10^{-5} \mathrm{M}\right)$ while varying the complex concentration $(\mathrm{ri}=[$ complex $] /[\mathrm{DNA}]=\mathrm{ri}=0,0.4$, $0.5)$.

Viscosity measurements were made using a viscosimeter (SCHOT AVS 450 ) maintained at $25.0 \pm 0.5^{\circ} \mathrm{C}$ using a constant temperature bath. The DNA concentration was fixed at $5 \times 10^{-5} \mathrm{M}$, and flow time was measured with a digital stopwatch. The mean values of three measurements were used to evaluate the viscosity $\eta$ of the samples. The values for relative specific viscosity $\left(\eta / \eta_{0}\right)^{1 / 3}$, where $\eta_{0}$ and $\eta$ are the specific viscosity contributions of DNA in the absence $\left(\eta_{0}\right)$ and in the presence of the complex $(\eta)$, were plotted against ri ( $\mathrm{ri}=$ $[$ complex $] /[\mathrm{DNA}]=0.0-2.5)$.

All fluorescence measurements were carried out with a JASCO spectrofluorometer (FP6200) by keeping the concentration of complex constant while varying the DNA concentration from 0 to $36 \times 10^{-5} \mathrm{M}$ ( ri $=[\mathrm{DNA}] /[$ complex $]=0.0$, $0.5,1.0,1.5,3,3.5)$ at three different temperatures $(288,298$, $308 \mathrm{~K})$.

The cyclic voltammetric measurements were performed using an AUTOLAB model (PG STAT C), with a three-electrode system: a $0.10 \mathrm{~cm}$ diameter glassy carbon (GC) disc as working electrode, an $\mathrm{Ag} / \mathrm{AgCl}$ electrode as reference electrode, and a Pt wire as counter electrode. Electrochemical experiments were carried out in a $25-\mathrm{mL}$ voltammetric cell at room temperature. All potentials are referred to the $\mathrm{Ag} / \mathrm{AgCl}$ reference. Their surfaces were freshly polished with $0.05 \mathrm{~mm}$ alumina prior to each experiment and were rinsed using double-distilled water between each polishing step. The supporting electrolyte was $0.01 \mathrm{M}$ of Tris-HCl buffer solution (pH 7.4) which was prepared with double-distilled water. Before experiments, the solution was deaerated via purging with pure nitrogen gas for $1 \mathrm{~min}$, and, during measurements a stream of nitrogen was passed over the solution. The current-potential curves and experimental data were recorded on software GPES [25].

\section{Results and Discussion}

3.1. Synthesis and Characterization of $[\mathrm{Pt}(\mathrm{DMP})(\mathrm{DIP})] \mathrm{Cl}_{2}$. $\mathrm{H}_{2} \mathrm{O}$ Complex. The mixed ligand platinum(II) complex of 4,4-dimethyl-2,2-bipyridine (DMP) and 4,7-diphenyl-1,10phenantroline (DIP) has been synthesized in aqueous methanol solution using $\mathrm{K}_{2} \mathrm{PtCl}_{4}$. The complex conforms to the formula $[\mathrm{Pt}(\mathrm{DMP})(\mathrm{DIP})] \mathrm{Cl}_{2} \cdot \mathrm{H}_{2} \mathrm{O}$, determined on the basis of elemental analysis.

The IR spectrum of the complex was characterized by the appearance of a band at $532 \mathrm{~cm}^{-1}$ due to the $[\nu(\mathrm{Pt}-\mathrm{N})]$. The coordination of the nitrogen atoms is confirmed with the presence of this band. However, the broad band at 3400$3500 \mathrm{~cm}^{-1}$ is assigned to $\left[\nu\left(\mathrm{H}_{2} \mathrm{O}\right)\right]$. Other bands are at $3050-$ $3236[\nu(\mathrm{C}-\mathrm{H})], 1230[\nu(\mathrm{C}-\mathrm{N})]$, and $1560[\nu(\mathrm{C}=\mathrm{N})]$, respectively.
${ }^{1} H$ NMR (d6-DMSO). In the aromatic region the signals at $\delta=8.3, \delta=8.1$ and $\delta=7.1 \mathrm{ppm}$ were assigned to protons of DMP ligands and the signals at $\delta=8.9, \delta=7.6, \delta=7.5$, and $\delta=7.3$ were assigned to the protons of DIP ligand. The protons of DMP and DIP ligands are seen to be shifted $(\approx-0.2 \mathrm{ppm})$ with corresponding free ligand and suggesting complexation.

3.2. UV-VIS Spectroscopy. Absorption spectroscopy is one of the most useful techniques to study the binding of any drug to DNA. The extent of hypochromism generally indicates the intercalative binding strength [26]. The hypochromicity characteristic of intercalation has usually been attributed to the interaction between the electronic states of the compound and those of the DNA bases [27], while the red shift has been associated with the decrease in the energy gap between the HOMO and LUMO molecular orbitals after binding of the complex to DNA [28]. Hyperchromism has been observed for the interaction of many drugs with DNA [29]. The hyperchromic effect might be ascribed to external contact (electrostatic binding [30]) or to partial uncoiling of the helix structure of DNA, exposing more bases of the DNA [31]. We have observed $4 \mathrm{~nm}$ bathochromic shift of the absorption band at $280 \mathrm{~nm}$ along with significant hypochromicity for the absorption band of the complex. This observation gives a good evidence of the intercalation of $\mathrm{Pt}$ (II) complex through the stacking and interaction of the aromatic rings of the ligands and the base pairs of DNA [32]. Additionally, based on the absorbance values obtained in the spectroscopic titration, the $[\mathrm{Pt}(\mathrm{DMP})(\mathrm{DIP})] \mathrm{Cl}_{2} \cdot \mathrm{H}_{2} \mathrm{O}$ complex-DNA binding constant, $K_{b}$, was calculated as described in the experimental procedure. The value obtained for $K_{b}$ was $2.0 \pm 0.2 \times 10^{4} \mathrm{M}^{-1}$. The values of $K_{b}$ described in the literature for classical intercalators (ethidium-DNA $7 \times$ $10^{7} \mathrm{M}^{-1}$ [33] and proflavin-DNA $4.1 \times 10^{5} \mathrm{M}^{-1}$ [34]) are at least 30 or 20 orders of magnitude higher than that obtained for this $\mathrm{Pt}(\mathrm{II})$ complex. This result suggests that intercalation between the base pairs is not the main mode of interaction of the Pt(II) complex with DNA. In contrast, the value of $K_{b}$ is ten orders of magnitude higher than the $K_{b}$ values which were found for compounds with the mode of groove binding like $\mathrm{Cr}$ (II) complexes [35] or tris (1,10-phen) ruthenium(II) to DNA [36]. These results confirm that the Pt(II) complex strongly interact with DNA, and the $K_{b}$ value obtained for this complex is of the same order of magnitude of that determined in analogues condition for $\mathrm{ZnL}^{+2}\left(K_{b}=7.36 \pm\right.$ $\left.0.01 \times 10^{4} \mathrm{M}^{-1}\right)$ which considered as an intercalating complex [37].

3.2.1. Circular Dichroism Spectroscopy. To establish in more detail whether binding of the complex brings about any significant conformational change of the DNA double helix, circular dichroism (CD) spectra of CT-DNA were recorded at increasing complex/CT-DNA ratios. The observed CD spectrum of natural calf thymus DNA consists of a positive band at $275 \mathrm{~nm}$ due to base stacking and a negative band at $245 \mathrm{~nm}$ due to helicity, which is characteristic of DNA in right-handed $\mathrm{B}$ form (Figure 3) [38]. The effect of the complex on 


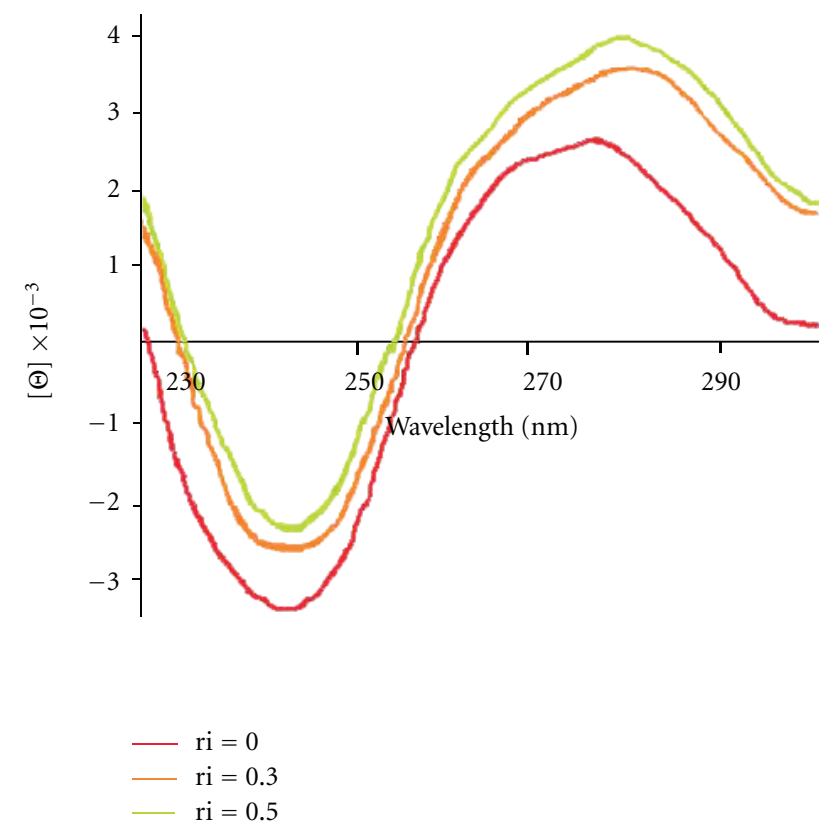

Figure 3: Circular dichroism spectra of CT-DNA $\left(5 \times 10^{-5} \mathrm{M}\right)$ in the presence of increasing amounts of $\mathrm{Pt}(\mathrm{II})$ complex at the following stoichiometric ratios ( $\mathrm{ri}=[$ complex $] /[\mathrm{DNA}]=0.0,0.4,0.5)$.

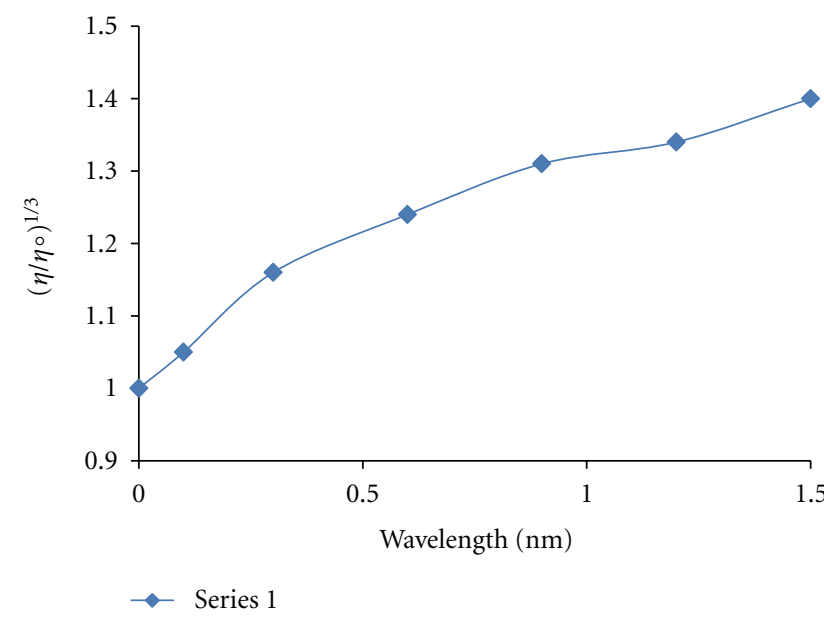

FIGURE 4: Effect of increasing amounts of Pt(II) complex on the viscosity of CT-DNA $\left(5 \times 10^{-5} \mathrm{M}\right)$ in $10 \mathrm{mM}$ Tris-HCl buffer.

the conformation of the secondary structure of DNA was studied by keeping the concentration of CT-DNA at $5 \times$ $10^{-5} \mathrm{M}$ while varying the concentration of complex in a buffer solution of $10 \mathrm{mM}$ of Tris ( $\mathrm{ri}=0,0.4,0.5$ ). The spectrum of the CT-DNA and those with the additives were monitored from 215 to $800 \mathrm{~nm}$. As shown in Figure 3, the CD spectrum of DNA exhibits a positive absorption at $282 \mathrm{~nm}$ due to the base stacking and a negative band at $240 \mathrm{~nm}$ due to the helicity of B-DNA. In the presence of the platinum(II) complex, the intensity of the positive peak increased and the intensity of the negative peak decreased. The changes in the
CD spectra in the presence of the complex show stabilization of the right-handed B form of CT-DNA (Figure 3).

3.2.2. Viscosity Measurements. The viscosity measurements of CT-DNA are regarded as the least ambiguous and the most critical tests of a binding model in solution in the absence of crystallographic structural data. The values of relative specific viscosity $\left(\eta / \eta_{0}\right)^{1 / 3}$ (where $\eta_{0}$ and $\eta$ are the specific viscosity contributions of DNA in the absence and in the presence of the $\mathrm{Pt}$ complex, resp.) were plotted against $1 / R(R=$ [DNA]/[complex]) (Figure 4). It is known that the groove binder like Hoechst 33258 does not cause an increase in the axial length of the DNA $[39,40]$ and, therefore, did not alter the relative viscosity. In contrast, cisplatin which is known to link DNA through covalent binding, shortening the axial length of the double helix [41], caused a decrease in the relative viscosity of the solution. Partial intercalators also reduce the axial length observed as a reduction in relative viscosity, whereas the classical organic intercalators such as ethidium bromide increased the axial length of the DNA, and it becomes more rigid $[39,40]$ resulting in an increase in the relative viscosity. Results confirm the sensitivity of viscosity measurements to the different modes of DNA binding. In this study, it was observed that increasing the platinum complex concentration leaded to an increase of the DNA viscosity. Thus, we may deduce that the $[\mathrm{Pt}(\mathrm{DMP})(\mathrm{DIP})] \mathrm{Cl}_{2} \cdot \mathrm{H}_{2} \mathrm{O}$ complex certainly is a DNA intercalator. Since the interaction of this platinum(II) complex with DNA can make DNA longer, we would expect that the relative viscosity of DNA increases with a slope between 0 and 0.94 (a value measured for ethidium bromide [42] if the intercalation of the $\mathrm{Pt}$ (II) complex was either only one interaction mode or much stronger than other interaction(s) (Figure 6). But, in this study, the relative viscosity of DNA increases with a slope of 0.38 (Figure 4) and it is reasonably believed that may be other interaction(s) between DNA and the $\mathrm{Pt}(\mathrm{II})$ complex occurred, and is reasonable for the decrease of the slope. In addition, it should be noted that the DNA binding constant measured for this $\mathrm{Pt}(\mathrm{II})$ complex is lower than those determined for ethidium bromide. Therefore, the greater increase in viscosity observed for ethidium bromide compared to the $\mathrm{Pt}$ (II) complex is likely due to the lower binding constant of the latter to DNA. These results clearly show the importance of using several techniques to ascertain intercalation.

3.2.3. Fluorescence Studies. To further investigate the interaction mode between the complex and CT-DNA, fluorescence titration experiments was performed. The complex emits luminescence in Tris-HCl buffer with maximum wavelengths of about $386 \mathrm{~nm}$. Figure 5 shows the emission spectra of the complex in the absence and presence of varying amounts of CT-DNA. In the emission spectra for the complex, with increasing CT-DNA concentration the emission intensity is decreased due to self-stacking of some free bases in the compound along the DNA surface [43]. Quenching can occur by different mechanisms, which are usually classified as dynamic and static quenching. Dynamic quenching refers to 


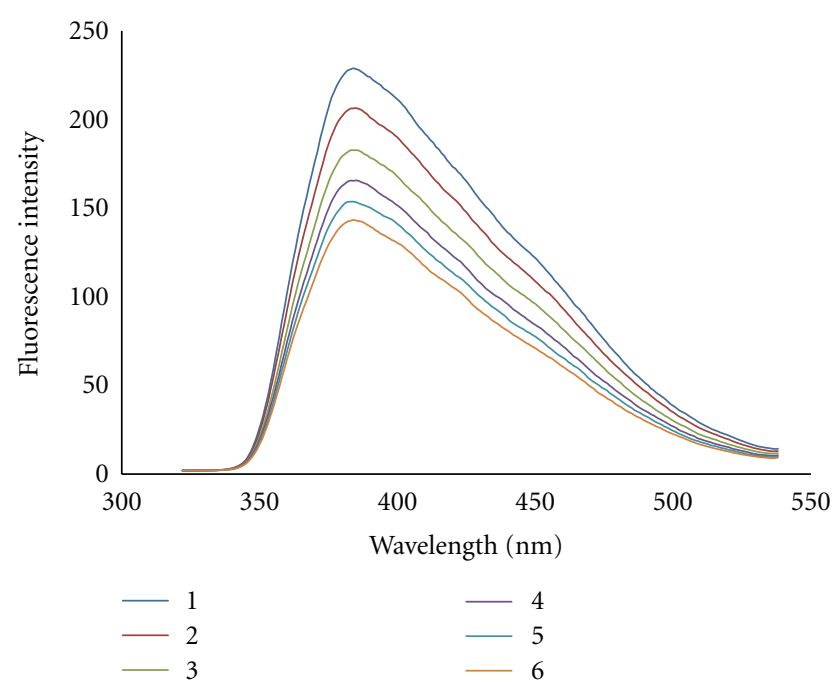

FIgURE 5: Fluorescence spectra of $\mathrm{Pt}(\mathrm{II})$ complex in the several concentrations of CT-DNA.

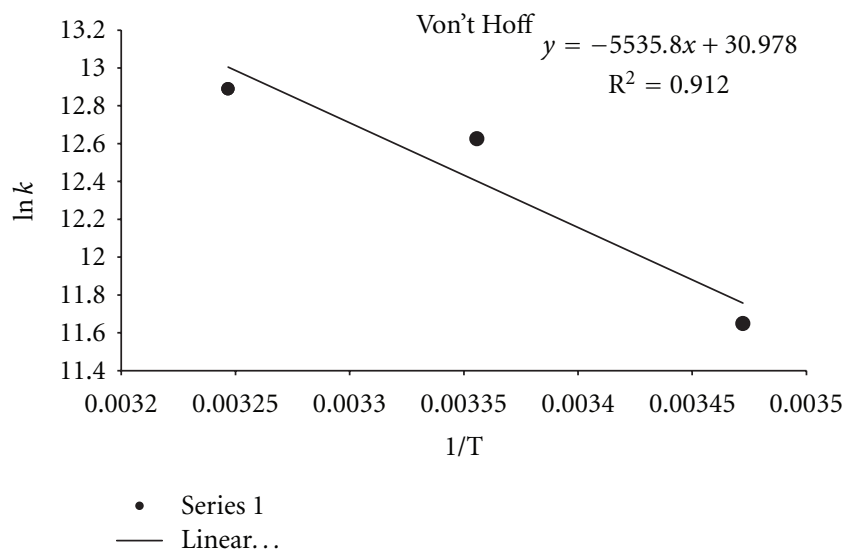

Figure 6: Van't Hoff plot for the interaction of the Pt(II) complex and CT-DNA at $\mathrm{pH}$ 7.2.

a process in which the fluorophore and the quencher come into contact during the transient existence of the exited state, while static quenching refers to fluorophore-quencher complex formation. In general, dynamic and static quenching can be distinguished by their differing dependence on temperature and excited state lifetime. Since in both cases the fluorescence intensity is related to the concentration of the quencher, the quenched fluorophore can serve as an indicator for the quenching agent [44].

Fluorescence quenching is described by the Stern-Volmer equation:

$$
\frac{F_{0}}{F}=1+K_{q} \tau_{0}[Q]=1+K_{\mathrm{SV}}[Q]
$$

where $F_{0}$ and $F$ represent the fluorescence intensities in the absence and in the presence of quencher, respectively. $K_{q}$ is the fluorophore quenching rate constant, $K_{\mathrm{SV}}$ is quenching constant, $\tau_{0}$ is the lifetime of the fluorophore in the absence of a quencher $\left(\tau_{0}=10^{-8}\right)$, and $[Q]$ is the concentration of
TABLe 1: The quenching constants of the Pt(II) complex by CTDNA at different temperatures.

\begin{tabular}{lccc}
\hline$T(\mathrm{~K})$ & $R^{2}$ & $K_{\mathrm{SV}}\left(\mathrm{Lmol}^{-1}\right) \times 10^{5}$ & $K_{q}\left(\mathrm{Lmol}^{-1}\right) \times 10^{13}$ \\
\hline 288 & 0.9946 & 3.53 & 3.53 \\
298 & 0.9981 & 5.42 & 5.42 \\
308 & 0.9965 & 10.34 & 10.34 \\
\hline
\end{tabular}

TABLE 2: Binding constants $\left(K_{f}\right)$ and number of binding sites $(n)$ of the complex-DNA system.

\begin{tabular}{lcccc}
\hline$T(\mathrm{~K})$ & $n$ & $\log K_{f}$ & $K_{f}$ & $R^{2}$ \\
\hline 288 & 0.919 & 5.06 & $1.14 \times 10^{5}$ & 0.9979 \\
298 & 0.958 & 5.48 & $3.04 \times 10^{5}$ & 0.9993 \\
308 & 0.931 & 5.60 & $3.96 \times 10^{5}$ & 0.9991 \\
\hline
\end{tabular}

quencher [45]. The results in Table 1 indicate that the probable quenching mechanism of this complex by CT-DNA involves static quenching, because $K_{\mathrm{SV}}$ decreases with increasing temperature [46].

3.3. Binding Constant and the Number of Binding Sites. If it is assumed that there are similar and independent binding sites in the biomolecule, the binding constant $\left(K_{f}\right)$ and the number of binding sites $(n)$ can be determined according to the method described by $\mathrm{Hu}$ et al. [47], using the following equation:

$$
\log \left(\frac{F_{0}-F}{F}\right)=\log K_{f}+n \log [Q] .
$$

Here, $F_{0}$ and $F$ are the fluorescence intensities of the fluorophore in the absence and presence of different concentrations of CT-DNA, respectively. The values of $K_{f}$ and $n$ were found to be $1.14 \times 10^{5} \mathrm{M}^{-1}$ and 1 , respectively, (Table 2).

3.3.1. Binding Mode between the Complex and DNA. According to the thermodynamic data, interpreted as follows, the model of interaction between a drug and biomolecule can be [48] (1) $\Delta H<0$ and $\Delta S<0$, hydrophobic forces; (2) $\Delta H>0$ and $\Delta S>0$, van der Waals interactions and hydrogen bonds; (3) $\Delta H>0$ and $\Delta S<0$, electrostatic interactions [49]. In order to elucidate the interaction of our complex with DNA, the thermodynamic parameters were calculated. The plot of $\ln K$ versus $1 / T$ (Figure 4 ; (4)) allows the determination of $\Delta H$ and $\Delta S$. If the temperature does not vary significantly, the enthalpy change can be regarded as a constant. Based on the binding constants at different temperatures, the free energy change can be estimated (Table $3 ;(5)$ ) by the following equations

$$
\begin{gathered}
\operatorname{Ln} K=-\frac{\Delta H}{R T}+\frac{\Delta S}{R T}, \\
\Delta G=\Delta H-T \Delta S=-R T \operatorname{Ln} K,
\end{gathered}
$$

where $K$ is the Stern-Volmer quenching constant at the corresponding temperatures and $R$ is the gas constant. When we apply this analysis to the binding of the complex with CTDNA, we find that $\Delta H>0$ and $\Delta S>0$. Therefore, van 


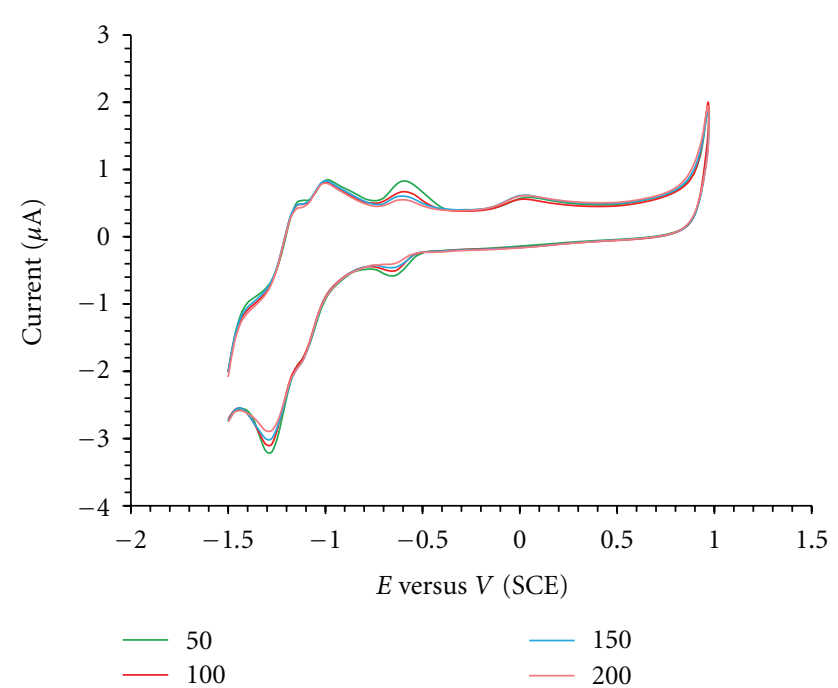

Figure 7: Cyclic voltametry for the Pt (II) complex $\left(10^{-3} \mathrm{~mol} / \mathrm{L}\right)$ at the presence of different concentrations of DNA.

TABle 3: Thermodynamic parameters for the binding of the Pt(II) complex to CT-DNA.

\begin{tabular}{lccc}
\hline$T(\mathrm{~K})$ & $\begin{array}{c}\Delta G \\
\left(\mathrm{KJ} \mathrm{mol}^{-1}\right)\end{array}$ & $\begin{array}{c}\Delta H \\
\left(\mathrm{KJ} \mathrm{mol}^{-1}\right)\end{array}$ & $\begin{array}{c}\Delta S \\
\left(\mathrm{~J} \mathrm{~mol}^{-1} \mathrm{~K}^{-1}\right)\end{array}$ \\
\hline 288 & -28.15 & 46.03 & 257.55 \\
298 & -30.73 & 46.03 & 257.55 \\
308 & -33.30 & 46.03 & 257.55 \\
\hline
\end{tabular}

der Waals interactions are probably the main forces in the binding of the investigated complex to CT-DNA.

3.4. Electrochemical Behaviour of the Complex in the Absence and Presence of CT-DNA. Recently, the electrochemical techniques extensively were used as a simple and rapid method to study DNA interaction with different compounds. The electrochemical behaviour of platinum is well known and was strongly influenced by the electrode material. A well-defined and sensitive peak was observed from the solutions of the complex with a GC electrode rather than the Pt one. Therefore, a GC electrode was used in this investigation. When CT-DNA is added to a solution of the complex, both the anodic and cathodic peak current heights of the complex decreased in the same manner of increasing additions of DNA, (Figure 7). Also during DNA addition, the anodic peak potential (Epa), cathodic peak potential (Epc), and $E_{1 / 2}$ (calculated as the average of Epc and Epa) all showed positive shifts. These positive shifts are considered as evidences for intercalation of the complex into the DNA, because this kind of interaction is due to hydrophobic interaction. From the other point of view, if a molecule binds electrostatically to the negatively charged deoxyribose-phosphate backbone of DNA, negative peak potential shifts should be detected. Therefore, the positive shift in the CV peak potentials of complex is indicative of intercalative binding mode of the complex with DNA [25].

\section{Conclusion}

In this paper, we investigate synthesis and characterization of new platinum(II) complex, and binding with CT-DNA was studied. The results suggest that the complex binds to DNA via intercalation mode. Spectrophotometry showed $4 \mathrm{~nm}$ bathochromic shift of the absorption band at $280 \mathrm{~nm}$ along with significant hypochromicity for the absorption band of the complex. The intristic binding constant $\left(K_{b}=2 \times\right.$ $10^{4} \mathrm{M}^{-1}$ ) is more in keeping with intercalators and suggest this binding mode. The viscosity measurement showed that the complex-DNA interaction can be hydrophobic and confirm intercalation. Moreover, the complex induced detectable changes in the CD spectrum of CT-DNA. The fluorescence studies revealed that the probable quenching mechanism of fluorescence of the complex by CT-DNA is static quenching. The thermodynamic parameters $(\Delta H>0$ and $\Delta S>0)$ showed that van der Waals interactions occurred that is intercalation mode. Also, CV results confirm this mode because, with increasing CT-DNA concentration, shift to higher potential was observed.

\section{Acknowledgment}

Financial support from the Razi University Research Center is gratefully acknowledged.

\section{References}

[1] E. R. Jamieson and S. J. Lippard, "Structure, recognition, and processing of cisplatin-DNA adducts," Chemical Reviews, vol. 99, no. 9, pp. 2467-2498, 1999.

[2] S. D. Cummings, "Platinum complexes of terpyridine: synthesis, structure and reactivity," Coordination Chemistry Reviews, vol. 253, p. 449, 2009.

[3] B. Lippert, Ed., Cisplatin Chemistry and Biochemistry of a Leading Anticancer Compound, Helvetica Chimica Acta/Wiley$\mathrm{VCH}$, Zurich, Switzerland, 1999.

[4] J. Reedijk, "Why does cisplatin reach guanine-N7 with competing S-donor ligands available in the cell?" Chemical Reviews, vol. 99, no. 9, pp. 2499-2510, 1999.

[5] G. Natiley and M. Coluccia, "Trans-platinum drugs with phosphines and amines as carrier ligands induce apoptosis in tumor cells resistant to cisplatin," Coordination Chemistry Reviews, vol. 383, p. 216, 2001.

[6] K. W. Jannette, S. J. Lippard, G. A. Vassiliades, and W. R. Bauer, "Metallointercalation Reagents. 2-Hydroxyethanethiolato $\left(2,2^{\prime}, 2^{\prime \prime}\right.$-terpyridine)-platinum(II) Monocation Binds Strongly to DNA By Intercalation," Proceedings of the National Academy of Sciences of the United States of America, vol. 71, no. 10, pp. 3839-3843, 1974.

[7] J. K. Barton and S. J. Lippard, "Cooperative binding of a platinum metallointercalation reagent to poly(A).poly(U)," Biochemistry, vol. 18, no. 12, pp. 2661-2668, 1979.

[8] B. M. Zeglis, V. C. Pierre, and J. K. Barton, "Metallo-intercalators and metallo-insertors," Chemical Communications, vol. 44, pp. 4565-4579, 2007.

[9] X. W. Liu, J. Li, H. Li, K. C. Zheng, H. Chao, and L. N. Ji, “Synthesis, characterization, DNA-binding and photocleavage of complexes $\left[\mathrm{Ru}(\mathrm{phen})_{2}(6-\mathrm{OH}-\mathrm{dppz})\right]^{2+}$ and $\left[\mathrm{Ru}(\mathrm{phen})_{2}\right.$ 
(6- $\left.\left.\mathrm{NO}_{2}-\mathrm{dppz}\right)\right]^{2+}$," Journal of Inorganic Biochemistry, vol. 99, no. 12, pp. 2372-2380, 2005.

[10] M. Howe-Grant and S. J. Lippard, "Laser temperature-jump study of stacking in adenylic acid polymers," Biochemistry, vol. 18, no. 26, pp. 5757-5762, 1979.

[11] A. M. Pyle, J. P. Rehmann, R. Meshoyrer, C. V. Kumar, N. J. Turro, and J. K. Barton, "Mixed-ligand complexes of ruthenium(II): factors governing binding to DNA," Journal of the American Chemical Society, vol. 111, no. 8, pp. 3051-3058, 1989.

[12] E. Wong and C. M. Giandornenico, "Current status of platinum-based antitumor drugs," Chemical Reviews, vol. 99, no. 9, pp. 2451-2466, 1999.

[13] W. D. McFadyen, L. P. G. Wakelin, I. A. G. Roos, and V. A. Leopold, "Activity of platinum(II) intercalating agents against murine leukemia L1210," Journal of Medicinal Chemistry, vol. 28, no. 8, pp. 1113-1116, 1985.

[14] C. Metcalfe and J. A. Thomas, "Kinetically inert transition metal complexes that reversibly bind to DNA," Chemical Society Reviews, vol. 32, no. 4, pp. 215-224, 2003.

[15] R. P. Bonomo, V. Cucinotta, G. Grasso, G. Maccarrone, and L. Mastruzzo, "Stereoselectivity in the interaction between an oligodeoxynucleotide and dipeptides in the presence of the copper(II) ion," Journal of Inorganic Biochemistry, vol. 70, no. 1, pp. 1-6, 1998.

[16] S. Mahadevan and M. Palaniandavar, "Spectroscopic and voltammetric studies of copper (II) complexes of bis(pyrid-2yl)-di/trithia ligands bound to calf thymus DNA," Inorganica Chimica Acta, vol. 254, no. 2, pp. 291-302, 1997.

[17] C. A. Mitsopoulou, C. E. Dagas, and C. Makedonas, "Synthesis, characterization, DFT studies and DNA binding of mixed platinum (II) complexes containing quinoxaline and 1,2-dithiolate ligands," Journal of Inorganic Biochemistry, vol. 102, no. 1, pp. 77-86, 2008.

[18] M. Carcell, P. Mazzo, C. Pelizzi, and F. Zani, "Antimicrobial and genotoxic activity of 2,6-diacetylpyridine bis(acylhydrazones) and their complexes with some first transition series metal ions. X-ray crystal structure of a dinuclear copper(II) complex," Journal of Inorganic Biochemistry, vol. 57, pp. 43-62, 1995.

[19] V. G. Vaidyanathan and B. U. Nair, "Oxidative cleavage of DNA by tridentate copper (II) complex," Journal of Inorganic Biochemistry, vol. 93, no. 3-4, pp. 271-276, 2003.

[20] C. A. Mitsopoulou, C. E. Dagas, and C. Makedonas, "Characterization and DNA interaction of the $\mathrm{Pt}(\mathrm{II})(\mathrm{pq})(\mathrm{bdt})$ complex: a theoretical and experimental research," Inorganica Chimica Acta, vol. 361, no. 7, pp. 1973-1982, 2008.

[21] A. R. Bahrami, M. J. Dickman, M. M. Matin et al., "Use of fluorescent DNA-intercalating dyes in the analysis of DNA via ion-pair reversed-phase denaturing high-performance liquid chromatography," Analytical Biochemistry, vol. 309, no. 2, pp. 248-252, 2002.

[22] S. D. Kennedy and R. G. Bryant, "Manganese-deoxyribonucleic acid binding modes. Nuclear magnetic relaxation dispersion results," Biophysical Journal, vol. 50, no. 4, pp. 669-676, 1986.

[23] S. Kashanian, M. B. Gholivand, F. Ahmadi, A. Taravati, and A. H. Colagar, "DNA interaction with Al-N,N, $N^{\prime}$-bis(salicylidene)2,2'-phenylendiamine complex," Spectrochimica Acta A, vol. 67, no. 2, pp. 472-478, 2007.

[24] A. Wolfe, G. H. Shimer, and T. Meehan, "Polycyclic aromatic hydrocarbons physically intercalate into duplex regions of denatured DNA," Biochemistry, vol. 26, no. 20, pp. 6392-6396, 1987.
[25] Y. Ni, D. Lin, and S. Kokot, "Synchronous fluorescence, UVvisible spectrophotometric, and voltammetric studies of the competitive interaction of bis(10-phenanthroline)copper(II) complex and neutral red with DNA," Analytical Biochemistry, vol. 352, no. 2, pp. 231-242, 2006.

[26] J. K. Barton, J. J. Dennenberg, and J. B. Chaires, “Tris(phenanthroline)ruthenium(II) enantiomer interactions with DNA: mode and specificity of binding," Biochemistry, vol. 32, no. 10, pp. 2573-2584, 1993.

[27] B. D. Wang, Z. Y. Yang, P. Crewdson, and D. Q. Wang, "Synthesis, crystal structure and DNA-binding studies of the Ln(III) complex with 6-hydroxychromone-3-carbaldehyde benzoyl hydrazone," Journal of Inorganic Biochemistry, vol. 101, no. 10, pp. 1492-1504, 2007.

[28] F. Arjmand and M. Aziz, "Synthesis and characterization of dinuclear macrocyclic cobalt(II), copper(II) and zinc(II) complexes derived from 2,2,2' $2^{\prime}$-S,S [bis(bis-N,N-2-thiobenzimidazolyloxalato-1,2-ethane)]: DNA binding and cleavage studies," European Journal of Medicinal Chemistry, vol. 44, no. 2, pp. 834-844, 2009.

[29] P. J. Cox, G. Psomas, and C. A. Bolos, "Characterization and DNA-interaction studies of 1-dicyano-2,2-ethylene dithiolate $\mathrm{Ni}$ (II) mixed-ligand complexes with 2-amino-5-methyl thiazole, 2-amino-2-thiazoline and imidazole. Crystal structure of $\left[\mathrm{Ni}(\mathrm{i}-\mathrm{MNT})(2 \mathrm{a}-5 \mathrm{mt})_{2}\right]$," Bioorganic and Medicinal Chemistry, vol. 17, no. 16, pp. 6054-6062, 2009.

[30] R. F. Pasternack, E. J. Gibbs, and J. J. Villafranca, "Interactions of porphyrins with nucleic acids," Biochemistry, vol. 22, no. 10, pp. 2406-2414, 1983.

[31] G. Pratviel, J. Bernadou, and B. Meunier, "DNA and RNA cleavage by metal complexes," Advances in Inorganic Chemistry, vol. 45, pp. 251-312, 1998.

[32] T. Uno, K. Hamasaki, M. Tanigawa, and S. Shimabayashi, "Binding of meso-Tetrakis(N-methylpyridinium-4-yl)porphyrin to Double Helical RNA and DNA. RNA Hybrids," Inorganic Chemistry, vol. 36, no. 8, pp. 1676-1683, 1997.

[33] M. J. Waring, "Complex formation between ethidium bromide and nucleic acids," Journal of Molecular Biology, vol. 13, no. 1, pp. 269-282, 1965.

[34] Y. Baba, C. L. Beathy, A. Kagemato, and C. Gebelien, Biological Activity of Polymers, vol. 186 of ACS Symposium Series, American Chemical Society, Washington, DC, USA, 1962.

[35] R. Vijayalakshmi, M. Kanthimathi, V. Subramanian, and B. U. Nair, "Interaction of DNA with [Cr(Schiff base)(H2O)2] ClO4," Biochimica et Biophysica Acta, vol. 1475, no. 2, pp. 157$162,2000$.

[36] M. Eriksson, M. Leijon, C. Hirot, B. Norden, and A. Graeslund, "Minor groove binding of $[\mathrm{Ru}($ phen)3]2+ to [d(CGCGATCGCG)] 2 evidenced by two-dimensional NMR," Journal of the American Chemical Society, vol. 114, pp. 4933-4934, 1992.

[37] A. Silvestri, G. Barone, G. Ruisi, D. Anselmo, S. Riela, and V. T. Liveri, "The interaction of native DNA with $\mathrm{Zn}$ (II) and $\mathrm{Cu}(\mathrm{II})$ complexes of 5-triethyl ammonium methyl salicylidene ortophenylendiimine," Journal of Inorganic Biochemistry, vol. 101, no. 5, pp. 841-848, 2007.

[38] S. Ramakrishnan and M. Palaniandavar, "Interaction of rac$[\mathrm{Cu}$ (diimine) 3$] 2+$ and rac- $[\mathrm{Zn}$ (diimine) 3$] 2+$ complexes with CT DNA: effect of fluxional $\mathrm{Cu}(\mathrm{II})$ geometry on DNA binding, ligand-promoted exciton coupling and prominent DNA cleavage," Journal of Chemical Sciences, vol. 117, pp. 179186, 2005. 
[39] E. C. Long and J. K. Barton, "On demonstrating DNA intercalation," Accounts of Chemical Research, vol. 23, pp. 271-273, 1990.

[40] D. Suh and J. B. Chaires, "Criteria for the mode of binding of DNA binding agents," Bioorganic and Medicinal Chemistry, vol. 3, no. 6, pp. 723-728, 1995.

[41] L. Kapicak and E. J. Gabbay, "Topography of nucleic acid helixes in solutions. XXXIII. Effect of aromatic cations on the tertiary structures of deoxyribonucleic acid," Journal of the American Chemical Society, vol. 97, pp. 403-408, 1975.

[42] F. H. Li, G. H. Zhao, H. X. Wu et al., "Synthesis, characterization and biological activity of lanthanum(III) complexes containing 2-methylene-10-phenanthroline units bridged by aliphatic diamines," Journal of Inorganic Biochemistry, vol. 100, no. 1, pp. 36-43, 2006.

[43] E. Nyarko, N. Hanada, A. Habib, and M. Tabata, "Fluorescence and phosphorescence spectra of $\mathrm{Au}(\mathrm{III}), \mathrm{Pt}(\mathrm{II})$ and $\mathrm{Pd}(\mathrm{II})$ porphyrins with DNA at room temperature," Inorganica Chimica Acta, vol. 357, no. 3, pp. 739-745, 2004.

[44] F. L. Cui, J. Fan, J. P. Li, and Z. D. Hu, "Interactions between 1-benzoyl-4-p-chlorophenyl thiosemicarbazide and serum albumin: investigation by fluorescence spectroscopy," Bioorganic and Medicinal Chemistry, vol. 12, no. 1, pp. 151-157, 2004.

[45] Y. Sun, S. Bi, D. Song, C. Qiao, D. Mu, and H. Zhang, "Study of interactions of anthraquinones with DNA using ethidium bromide as a fluorescence probe," Sensors and Actuators B, vol. 129, pp. 799-810, 2008.

[46] P. B. Kandagal, S. M. T. Shaikh, D. H. Manjunatha, J. Seetharamappa, and B. S. Nagaralli, "Spectroscopic studies on the binding of bioactive phenothiazine compounds to human serum albumin," Journal of Photochemistry and Photobiology A, vol. 189, no. 1, pp. 121-127, 2007.

[47] Y. J. Hu, H. G. Yu, J. X. Dong, X. Yang, and Y. Liu, "Spectroscopic studies on the interaction between 3,4,5-trimethoxybenzoic acid and bovine serum albumin," Spectrochimica Acta A, vol. 65, no. 3-4, pp. 988-992, 2006.

[48] D. B. Naik, P. N. Moorthy, and K. I. Priyadarsini, "Nonradiative energy transfer from 7-amino coumarin dyes to thiazine dyes in methanolic solutions," Chemical Physics Letters, vol. 168, no. 6, pp. 533-538, 1990.

[49] N. Shahabadi and A. Fatahi, "Multispectroscopic DNA-binding studies of a tris-chelate nickel(II) complex containing 4,7-diphenyl 10-phenanthroline ligands," Journal of Molecular Structure, vol. 970, no. 1-3, pp. 90-95, 2010. 


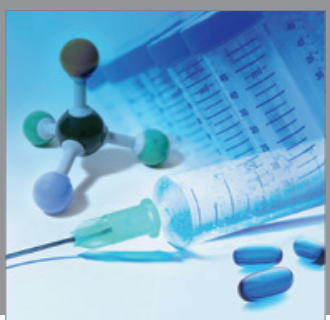

International Journal of

Medicinal Chemistry

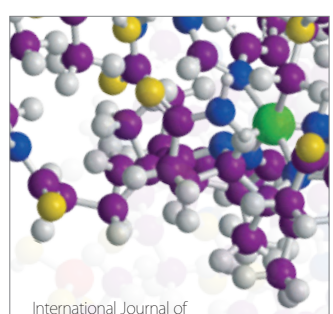

Carbohydrate Chemistry

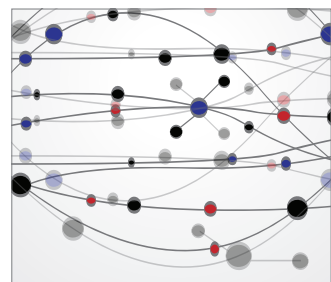

The Scientific World Journal
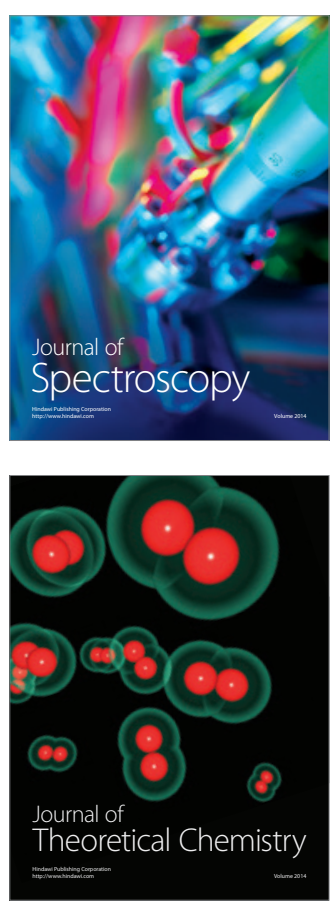
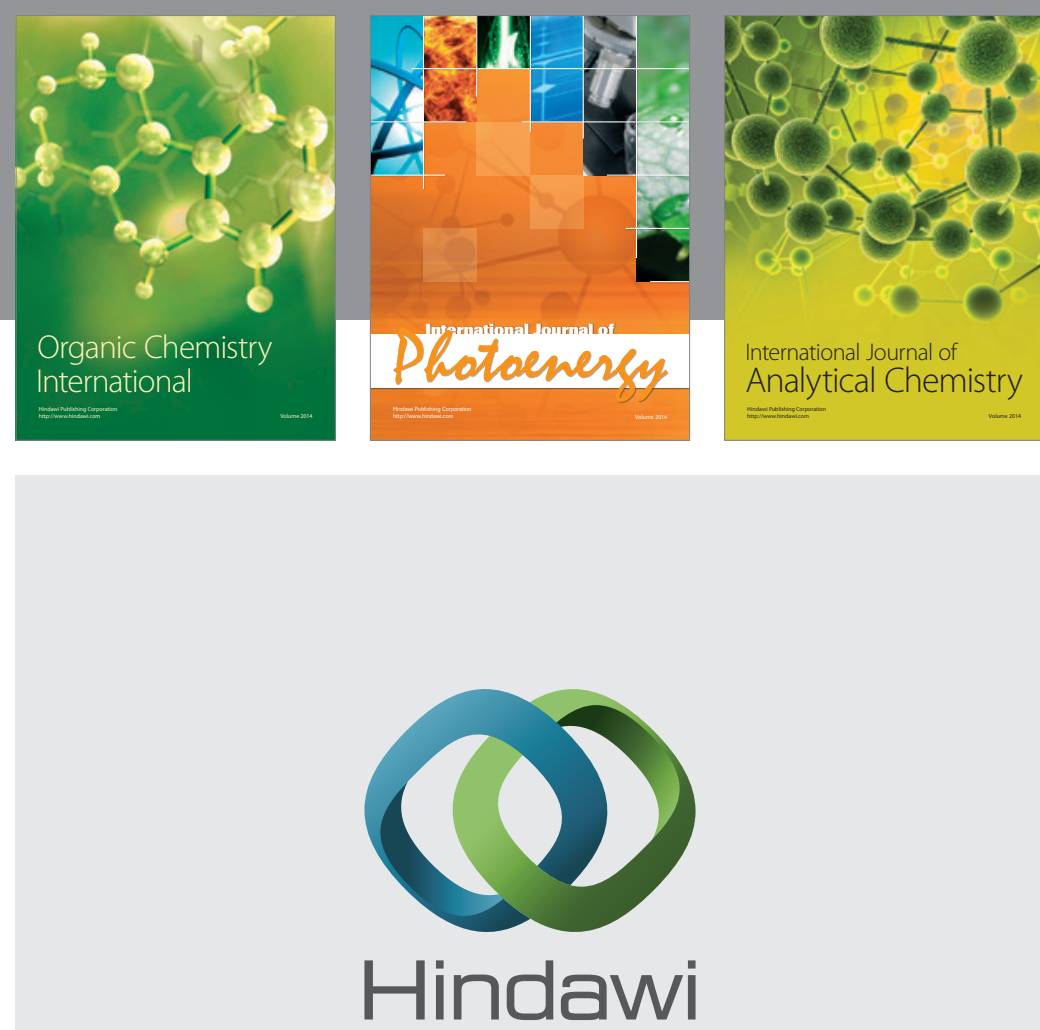

Submit your manuscripts at

http://www.hindawi.com
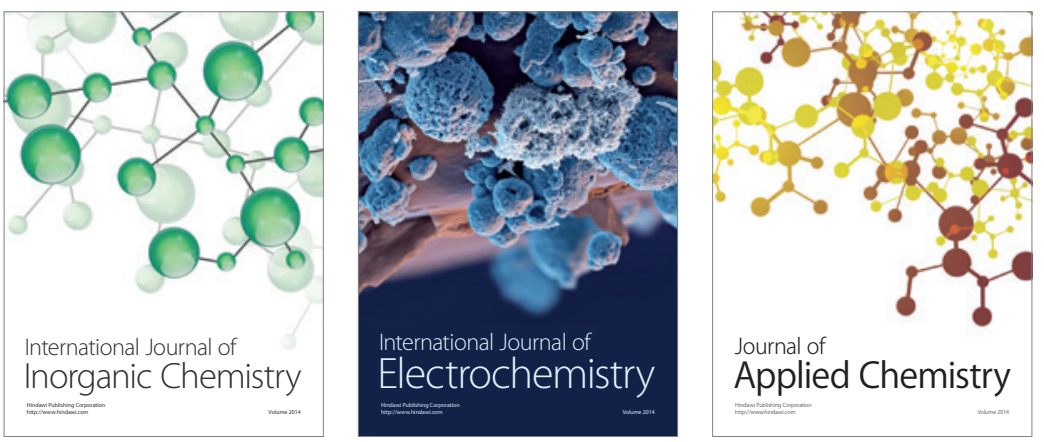

Journal of

Applied Chemistry
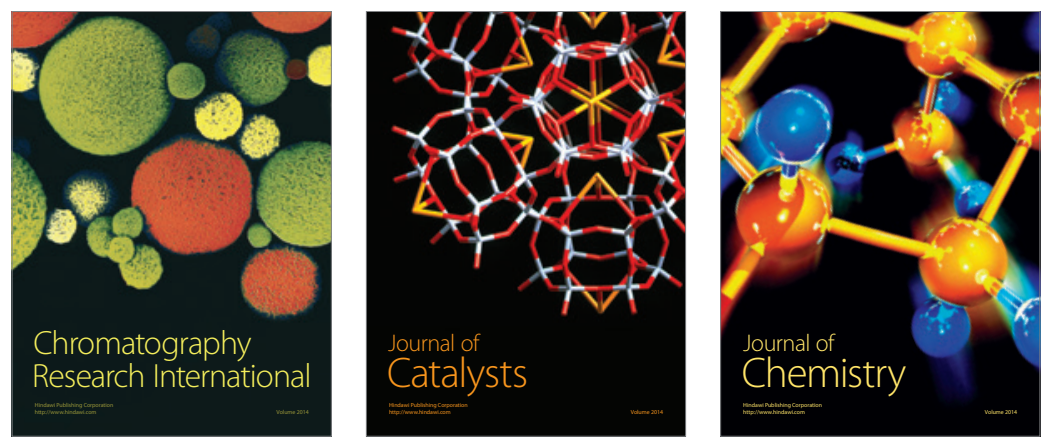
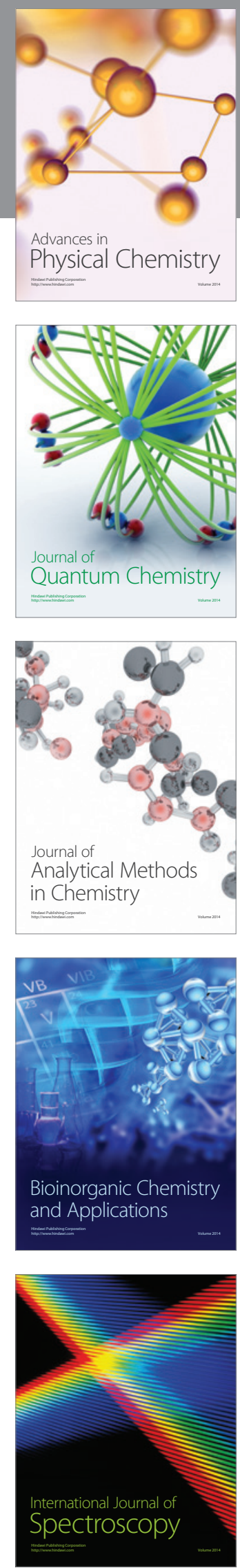